\title{
Áldozathibáztatás kisebbségi csoportok sértettjeivel szemben
}

\author{
Bárd Petra' - Szontagh Veronika Anna² \\ https://doi.org/10.51624/SzocSzemle.2021.1.2 \\ Beérkezés: 2020. 12. 19. \\ Átdolgozott változat beérkezése: 2021. 03. 10. \\ Elfogadás: 2021. 03. 23.
}

\begin{abstract}
Összefoglaló: Az igazságszolgáltatási szervek, valamint a média és a közvélemény egyaránt gyakran bocsátkozik áldozathibáztatásba, amikor sérülékeny kisebbségek tagjai válnak büncselekmény sértettjévé. Az áldozathibáztatást a másodlagos viktimizáció egyik formájának tekintjük. Ilyenkor a társadalom a büncselekmények sértettjeit másodszor is cserben hagyja, sérelmüket bagatellizálva, valamint az elkövetők felelösségét kisebbítve, a velük szembeni állami rosszallást - akár büntetô szankció formájában - nem kellően kifejezve.

A tanulmány első részében ismertetjük az áldozathibáztatás fogalmának történetét, és bemutatjuk az áldozathibáztatás széleskörủen elterjedt társadalmi jelenségét. Mivel az áldozathibáztatást magyarázó elméletek sorából kiemelkedik a feminista irodalom, áttekintjük ennek tanításait a nőkkel szembeni elnyomás és a szexuális jellegủ bűncselekmények vonatkozásában. Ezután általában a kisebbségi csoportokkal szembeni intézkedésekkel és erőszakos cselekményekkel foglalkozunk. Tanulmányunk második felében régi és új elméletek fényében térképezzük fel az áldozathibáztatás lehetséges magyarázó okait és húzóerejét, abban a reményben, hogy a megértés hozzásegít az áldozatokra és az egész társadalomra nézve rendkívül káros jelenség leküzdéséhez.
\end{abstract}

Kulcsszavak: áldozathibáztatás, viktimizáció, nőkkel szembeni erőszak, gyülölet-büncselekmények

Jelen tanulmányban az áldozathibáztatás - mint a másodlagos viktimizáció egyik formája - alatt azt értjük, amikor egy büncselekmény megtörténtéért részben vagy egészében az áldozatot teszik felelőssé, csökkentve a tettes felelősségét, vagy felmentve őt a felelősség alól. A hibáztató hozzáállás jelentkezhet a hatóságok, az egészségügyi rendszer, a családtagok, a barátok részéről, de érkezhet a média irányából is.

Tanulmányunk első részében bemutatjuk az áldozathibáztatás széleskörűen elterjedt társadalmi jelenségét, továbbá részletesen tárgyaljuk, hogy az miért rendkívül káros mind az áldozatokra, mind az egész társadalomra nézve. Ismertetjük az áldozathibáztatás fogalmának történetét, majd a nőkkel szembeni elnyomás és

1 Eötvös Loránd Tudományegyetem, Állam és Jogtudományi Kar, Kriminológia Tanszék, email: bardp@ceu.edu. Jelen írás az MTA-ELTE Lendület SPECTRA Kutatócsoport (szerződésszám: LP2018-9/2018) keretén belül készült. A szerző a kutatócsoport vezetője. A szerzők köszönettel tartoznak Gönczöl Katalin professzor asszony és a két anonim lektor értő kritikájáért.

2 Társadalomtudományi Kutatóközpont, Jogtudományi Intézet, MTA Kiváló Kutatóhely, email: szontagh.veronikaanna@tk.hu. A szerző a SPECTRA kutatócsoport tagja. 
a szexuális jellegú bűncselekmények kontextusába helyezzük a jelenséget. Tágabban értelmezve is vizsgáljuk az áldozathibáztatást, kitérve a társadalmi struktúra és társadalmi egyenlőtlenségek kérdésére, az előítélet áldozataira, akik nemcsak a bűnbakképzés célpontjai, hanem akiket gyakran saját helyzetükért is felelőssé tesznek. Az áldozathibáztatás fő motivációja az erőszak, a társadalmi igazságtalanság igazolása. Célpontja gyakran valamely társadalmi kisebbséghez tartozik - jelen írásban ez alatt a kisebb hatalommal rendelkező társadalmi csoportokat értjük. A jelenséget mindennapi életünk emblematikus eseményeivel, hazai és külföldi példákkal illusztráljuk. A példák a világ minden tájáról érkeznek. A kulturális-társadalmi kontextus természetesen nem mindenhol azonos, így nem is lehet homogén masszaként kezelni sem a nőket, sem a más, hatalmi kisebbségben lévő csoportokat, illetve az általuk tapasztaltakat. A napi hírekből vett példák leírásának célja, hogy bemutassa: különböző formákban, de világszerte megjelenik a hibáztató attitűd.

Tanulmányunk második részében az áldozathibáztatás lehetséges magyarázó okait és húzóerejét ismertetjük. Ilyenek az elkövetők neutralizációs technikái, a tekintélyelvűség, a lopakodó determinizmus jelensége, az igazságos világba vetett hit, az áldozattal való együttérzés nehézsége, az áldozat idealizált képének való meg nem felelés, illetve az áldozatok önvádja. Az utolsó részben következtetéseinket foglaljuk össze.

\section{$\mathrm{Az}$ áldozathibáztatás mint elterjedt társadalmi jelenség: elméletek és példák}

\section{Kezdetek: a frankfurti iskola}

Tekintettel jelen tanulmány kritikai megközelítésére, kiindulópontunk a frankfurti iskola. ${ }^{3} \mathrm{Az}$ itt ismertetett teóriák nem tekinthetőek az áldozatokolás klasszikus elméleteinek, sokkal inkább elméleti megalapozásának. Régi és új elméletek sorát úgy fúztük fel, hogy segítséget kaphassunk a bűncselekmény társadalmi gyűlölettől motivált tettesének, a passzív többségnek és az áldozatot a büntetőeljárás során tovább viktimizáló igazságszolgáltatási rendszernek a megértéséhez.

Elsőként Teodor W. Adornót (1950) érdemes megemlíteni, a tekintélyelvű személyiség és az F(fasiszta)-skála megalkotóját. Az F-skála a tekintélyelvủ beállítottság mértékét tette mérhetővé. A tekintélyelvű személyiség egyik jellemzője a bűnbak-

3 A frankfurti iskola elméleti megközelítései sem előzmény nélküliek. A viktimológia egyik atyjának tekintett Hans von Hentig (1948) The Criminal and His Victime címú írásában már megjelenik az áldozathibáztatás jelensége, viszont a mű pozitivista megközelítése miatt nem vizsgálta az áldozattá válás folyamatának magyarázó okait, sem az áldozattá válásra reagáló társadalmi folyamatokat. Sőt, a sértett helyzete már a római jogban is foglalkoztatta a jogtudósokat, igaz a XII-XV. századig tartó egységes államiság kialakulásával párhuzamosan háttérbe szorult a téma. Amikor a megerősödött centralizált „állam a magánbosszút, a kompozíciót megtiltotta, és ezzel a büntetőjogot közjogiasította és monopolizálta, a bűncselekmény megszűnt a sértett magánügye lenni. Az individuum sérelmében is az állam sérelmét kellett látni, amely önmagát mindig és szívesen a közösség, az egész társadalom érdekeit védelmező bajnokaként láttatta." Az állam átvette a büntetés monopóliumát, és felvállalta, hogy „a bủncselekményt a sértett helyett maga torolja meg”, megelözve az önbíráskodást és a magánbosszút. A sértetti jogok újjáéledésére évszázadokat kellett várni. (Király 1988) 
képzés, a kisebbségi, a gyengébb társadalmi helyzetű csoportok értékeinek elítélése, elnyomása. Adorno szerint a tekintélyelvű személyiségű emberekben magas a frusztráció szintje, és az ezáltal kialakult agresszió gyakorta a gyengébb vagy hátrányos helyzetű csoportokra irányul. Ez már tekinthető egyfajta áldozathibáztatásnak, hiszen a tekintélyelvű személy saját frusztrációjának okaként a kisebbségi csoportokat tartja felelősnek. ${ }^{4}$

A frankfurti iskola keretein belül született meg a másodlagos antiszemitizmus elmélete is. A kifejezés Peter Schönbach (1961) - Adorno munkatársa - nevéhez kötődik. A másodlagos antiszemitizmus a Holokauszttal való szembenézés vagy a szembenézéssel való képtelenség következménye. A második világháborút követően a nyílt antiszemita megnyilvánulások társadalmilag ugyan elfogadhatatlanná váltak, ugyanakkor a zsidók puszta léte a soára emlékeztette a többségi társadalom tagjait, és a bűntudatukért megint csak a zsidókat okolták. Másodlagos antiszemitizmusból fakad a vád, miszerint a zsidók kihasználják a többségi társadalom tagjainak bűntudatát, és ezzel manipulálják őket. A másodlagos antiszemitizmus az áldozathibáztatás egy korai példája. ${ }^{5}$

Noha a frankfurti iskola teremtette meg az áldozathibáztatás elméleti alapjait, maga a fogalom csak később, az 1970-es években terjedt el. Az áldozathibáztatás kifejezést ekkor már tágabban, a társadalmi struktúrákból fakadó esélyegyenlőtlenségek, illetve a rasszizmus áldozatai vonatkozásában használták - az áldozat viktimológiai fogalmának legtágabb értelmében. A fogalom William Ryan (1971) pszichológus Blaming the Victim című könyvének megjelenésével vált népszerűvé.

\section{A nökkel szembeni erôszak és az áldozathibáztatás}

A nemi erōszak kultúrája, feminista elméletek

A jelentős tudományos előzmények ellenére az áldozathibáztatás fogalmát csak a feminista kriminológia tette a közbeszéd részévé és általánosan ismert fogalommá. Az 1970-es években jelentek meg a kriminológia területén azok a kritikai irányzatok - a kritikai kriminológia, kritikai feminista kriminológia, illetve a kritikai viktimológia -, amelyek újabb szemszögből vizsgálták az áldozattá válás folyamatát, illetve az azt követő társadalmi folyamatokat, mint az áldozathibáztatást és a másodlagos viktimizáció további formáit. A szexuális forradalom és az ezzel párhuzamosan kialakuló feminista mozgalom második generációja (1960-70-es évek) nagy hatással volt a kriminológiai gondolkodás alakulására, illetve a nők és férfiak társadalmi szerepeinek újragondolására. A második generációs feminista mozgal-

4 A bủnbakképzés újabb elméletei szerint nem is a frusztráció okozza az agressziót, hanem a bünbakképző ideológia elfogadása. Ez a megközelítés - ami az eredeti búnbakképzés elméletének kritikájaként is tekinthető - magyarázó erővel bírhat azokban az esetekben, ahol az áldozati csoport nem egy gyenge társadalmi csoport. Peter Glick (2002) Sacrificial Lambs Dressed in Wolves' Clothing című tanulmányában irigykedő előítéletként ír arról, amikor az áldozati csoport szocioökonómiai szempontból sikeres, kulturálisan befolyásos (lásd például a zsidók, örmények vagy a tuszik helyzetét). Ez az ideológiai búnbakképzés kevésbé igaz a gyengébb társadalmi csoportok esetében, ez utóbbi esetben sokkal inkább beszélhetünk megvető előítéletről.

5 A másodlagos antiszemitizmus elméletét, vagyis hogy a zsidók múltbéli tragédiáinak jelenkori megélése növelheti-e az antiszemitizmust, csak a 2000-es évek végén tesztelték empirikusan. Az empirikus kutatás eredményeihez lásd: Imhoff és Banse (2009). 
mak beszédtémává tették a nemi erőszak, a nemi erőszak kultúrájának ${ }^{6}$ problémáját, középpontba helyezték a női áldozatokat, leginkább pedig a családon belüli és a szexuális erőszak áldozatait.

Olyan, a szexista elnyomást magyarázó elméletek és koncepciók láttak napvilágot ebben az időszakban, mint például a patriarchális uralom vagy az igazságszolgáltatás, illetve szűkebben a büntetőjog maszkulin mivolta (Vig 2016). Az áldozathibáztatás pszichológiai és kriminológiai fogalmát fokozatosan a szexuális jellegű bűncselekményekhez társították. Az áldozathibáztatás központi eleme a nemi erőszak kultúrájának, ami fenntartja az elnyomást és normalizálja a verbális, fizikai és szexuális erőszakot, ideértve a szexuális jellegű bűncselekményeket is (BuchwaldFletcher-Roth 1993).

A nemi erőszak és szexuális zaklatás áldozatainak áldozathibáztatása sok szempontból káros jelenség: nemcsak tovább viktimizálja az áldozatot, de részleges vagy teljes felmentést ad egy olyan cselekményben, amely bűn, és amelyet a magyar Büntető Törvénykönyv is büntetni rendel. A nők hibáztatása kéz a kézben jár a férfiak gátlástalan ösztönlényként való ábrázolásával, ami nemcsak sértő, de téves is a férfinemre nézve, hiszen a férfiak többsége nem erőszakol meg nőket, függetlenül azok ruházatától, hajviseletétől, hanghordozásától vagy véralkohol- és drogszintjétől. A nők hibáztatása küllemükért, naivitásukért, kacérságukért stb. kriminológiai szempontból is téves üzenetet hordoz, hiszen a nemi erőszak több mint kétharmada ismerősök között valósul meg, és azon belül is nagy hányaduk családon belül. Az erőszak mítoszának elmélete éppen ezeket a tévképzeteket ismerteti és mutatja be. Martha Burt (1980) négy kategóriába sorolja ezeket a mítoszokat: (i) nemi erőszak megtörténtének tagadása (ha nem tett azonnal feljelentést, nem is történt meg); (ii) a nemi erőszak relativizálása (nem küzdött, ezért nem is volt erőszak); (iii) a szexuális aktus konszenzuális jellege (a zaklatás, erőszak áldozata is ezt akarta); végül (iv) áldozathibáztató attitűdöt megalapozó mítoszok (alkohol- vagy drogfogyasztás, provokatív öltözködés) (Szabó-Virág 2017). Burt megállapításai mind a mai napig helytállóak és velünk élő elképzelések. Az erőszak mítoszának elfogadása szorosan összefügg az áldozathibáztatással (Hayes-Lorenz-Bell 2013: 206), hiszen a mítoszok elfogadásával egy olyan áldozat képét jelenítik meg, aki maga tehet a cselekmény megtörténtéről (Ryan 2019). Suarez és Gadalla (2010) kutatása azt mutatja, hogy a nemi erőszak mítoszait a férfiak nagyobb arányban hajlamosak elfogadni, illetve hogy ez sokszor együtt jár a nőgyűlölettel és a szexizmussal. Továbbá a kutatás eredményei azt is jelzik, hogy az erőszak mítoszainak elfogadottsága korrelál a rasszizmussal, heteroszexizmussal vagy az ageizmussal. A \#MeToo-mozgalomban felszínre került ügyek is alátámasztják, hogy a nemi erőszak sokkal inkább szól a hatalomról és az erőfölénnyel történő visszaélésről, mint a szexről.

6 A nemi erőszak kultúrája kifejezést a második feminista hullám időszakában kezdték használni az 1970-es években. Írásos formában elöször 1974-ben jelent meg a kifejezés egy radikális feminista kiadványban: Rape: The First Sourcebook for Women. 1975-ben dokumentumfilm készült Rape Culture címmel. A nemi erőszak kultúrája azt a társadalmi berendezkedést, attitűdöt jelenti, amely tolerálja vagy normalizálja a nemi erőszakot. 
Egy 1998-as, az Országos Kriminológiai és Kriminalisztikai Intézetben (VirágKó 1998: 250-275) folytatott kutatás szerint a megkérdezettek csaknem fele egyetértett azzal az állítással, hogy „A megerőszakolt nők nagy része maga is tehet arról, hogy áldozattá vált”. 2011-ben egy potsdami kutatócsoport kimutatta, hogy a nemi erőszaknál jelentősen nagyobb az áldozathibáztatás mértéke, mint a betöréseknél. Amennyiben a sértett és az elkövető ismerték egymást, az áldozathibáztatás foka nőtt a nemi erőszaknál, míg a betöréses lopásoknál nem (Bienek-Krahé 2011).

A nemi erőszak nagy arányban látenciában marad, nem utolsósorban a szégyenérzet, a félelem, az anyagi függőség, a család, a másodlagos viktimizációtól való félelem és általában az igazságszolgáltatással szembeni bizalmatlanság miatt (Virág-Kulcsár-Rosta 2016). A nemi erőszak sértettjei az esetek 80 százalékában poszttraumás stresszreakciótól szenvednek (European Trauma Network), egy ausztrál kutatás (Rees et al. 2011) szerint pedig az áldozatok 35 százaléka később öngyilkosságot próbál meg elkövetni. Virág György (2001) kutatási eredményei szerint a szexuális abúzus áldozatai között kilencszeres az öngyilkosságot megkísérlők aránya. Ahogy Szabó Judit és Virág György (2017: 229) tanulmánya hangsúlyozza: „A trauma szégyenét a beszéd, a titkok feltárása oldhatja”. A beszéd gyógyító erejét ugyanakkor lerontja az áldozathibáztatás, hiszen a megnyugvás és igazság szolgáltatása helyett az ügyek napvilágra kerülésével az áldozatok tovább viktimizálódnak.

\section{Illusztráció: ${ }^{7}$ nemi erôszak, szexuális zaklatás}

A nemi erőszak női túlélőit különösen kegyetlenül büntetik a patriarchális társadalmak. Minél nagyobb tabuk övezik a szexualitást egy adott kultúrában, annál inkább stigmatizálják az áldozatokat. Ruandától Szudánig, Burmától Szíriáig kirekesztik a társadalomból, megbélyegzik, prostituáltként tartják nyilván, ${ }^{8}$ otthonuk elhagyására, válásra, vagy akár életük kioltására kényszerítik a megerőszakolt nőket, vagy családtagjaik ölik meg őket a „becsület” és „tisztesség” nevében.

Az áldozatok okolása, a magára hagyottság a fejlett világban élő nőket és lányokat is érinti. Egy 2011-es texasi ügyben két tucat tizenéves fiút és huszonéves férfit vádoltak egy tizenegy éves kislány csoportos megerőszakolása miatt. Az egyik elkövető védőügyvédje a tárgyaláson jelentőséget tulajdonított a gyermek provokatív ruházkodásának (Marcotte 2012). 2011 áprilisában egy torontói rendőr az áldozattá válás elkerülésének legjobb módjaként azt javasolta, hogy „a nők ne öltözzenek úgy, mint a ribancok" (Kwan 2011). (Erre válaszként, azaz az áldozat hibáztatása és a

7 A női egyenjogúság megvalósulása, a nők elnyomása nem azonos mértékú egy alkotmányos demokráciában és egy diktatúrában. Ahogy azonban az elsősorban a napi sajtóból vett példák mutatják, a nőkkel szembeni hibáztató attitűd világszerte problémát jelent.

8 Reményeink szerint az olvasó feleslegesnek ítéli ezt a jegyzetet, de a félreértések elkerülése érdekében fontosnak tartjuk hangsúlyozni, hogy a kirekesztés ezen formái alkotmányos demokráciákban értelmezhetetlenek. A jogegyenlőség elvével összhangban természetesen a prostituáltakkal szemben elkövetett nemi erőszak is erőszak. A Sex Educatio Alapítvány 2012-es kiadványában olvasható, hogy a prostitúcióból élő nők - kifejezetten igaz ez az utcai prostituáltakra - fokozottan ki vannak téve a nemi erőszak kockázatának. Az egyik leginkább hivatkozott, prostituáltak körében végzett kérdőíves kutatás eredménye azt mutatta, hogy a megkérdezettek 82 százalékát fizikailag bántalmazták, 68 százalékát megerőszakolták a prostitúció megkezdése óta (idézi Lőrincz 2009: 239). 
nemi erőszak kultúrája elleni tiltakozásként szervezték meg az első ún. Ribanc Sétát [BBC 2011], amelyet azán világszerte átvettek. Magyarországon 2014 novemberében, a nők elleni erőszak felszámolásának világnapján a Vas megyei rendőrség a fiatal lányok kacérkodását nevezte meg a nemi erőszak elkövetésének okaként [Police. hu 2014], valamint a pécsi rendőrség is vaskos áldozathibáztatásba bocsátkozott: nagy port kavaró, háromrészes bûnmegelőzési videójában ${ }^{9}$ ugyancsak a nemi erőszak áldozatát tette felelőssé a sértetté válásért. A spotok szlogenje magáért beszélt: „Tehetsz róla, tehetsz ellene” ${ }^{10}$ )

A nők elleni szexuális zaklatás és erőszak témája 2017-ben Harvey Weinstein hollywoodi filmproducer szexuális visszaélései kapcsán ${ }^{11}$ kapott nagy médiafigyelmet, és hosszú időre tematizálta a közbeszédet. A társadalmi vita egyértelművé tette, hogy a szexuális visszaélések a nők számára mindennapos tapasztalatok. A Weinstein-botrány által újra életre kelt \#MeToo ${ }^{12}$ mozgalomnak köszönhetően több mint száz nő jelezte, hogy a filmproducer vagy kéretlen szexuális ajánlatot tett, vagy nem kívánt szexuális érintkezésre kényszerítette őket, illetve többeket megerőszakolt (Réz 2019). A kampányban többen megkérdőjelezték az áldozatok hitelességét, szavahihetőségét, illetve Weinstein bírósági tárgyalásán is felmerültek olyan kijelentések, miszerint az áldozatok élvezték a szexet, vagy ki akarták használni a filmproducer hatalmát és befolyását, hogy így törjenek be a szórakoztatóiparba (Pilkington 2020). Az események nem korlátozódtak az Egyesült Államokra, a \#MeToo mozgalom hamar az egész világon elterjedt. Noha Magyarországon nem volt akkora hatása és következménye a kampánynak, mint például az Egyesült Államokban (Jámbor 2019), ${ }^{13}$ azért hazánkban is megtörték a csendet. Elsőként Sárosdi Lilla színésznő szólalt meg, majd egyre többen követték őt a múvészvilágból.

Ahogy az előző fejezetben említettük, a csend megtörése nem segít a bűncselekmény feldolgozásában és a megnyugvásban, ha mindez nem egy megértő közegben történik. Márpedig az igazságszolgáltatás gyakran ellenséges környezet az áldozatok számára. A büntetőeljárás során történő másodlagos viktimizáció tragikus példája Renner Erika ügye (Rab 2016). 2013-ban az áldozatot a kórházigazgatóként dolgozó volt barátja elkábította, és nemi szervét maró lúggal leöntötte. Az elkövetőt több mint hét év elteltével börtönbüntetésre ítélték, az ítélet 2020-ban vált jogerőssé. Az eljárás alatt az áldozatnak olyan kérdéseket szegeztek, hogy nem magán végzett-e öncsonkítást; mit tett azzal az emberrel, aki ilyen bűncselekményre vetemedett; illetve a hatóságok amiatt hibáztatták és azért kérdőjelezték meg a szavahi-

9 https://www.youtube.com/watch?v=rkV8M_767NU (a linkek letöltési dátuma: 2021. március 8.)

10 Cserháti Éva (Nők a Nőkért Együtt az Erőszak Ellen, NANE) egyenesen softpornóra hajazónak minősítette a spotokat, és valóban mintha a videó készítőjének szexuális fantáziáját tükrözné a kisfilm, különösen az a kevéssé életszerű jelenet, amelyben három fiatal nő bulira készülődve egymás előtt erotikusan eszik, iszik és hajat dobál. Ennek az üzenetértéke vagy értelmetlen (aki otthon kihívóan eszik hamburgert, azt az utcán megerőszakolják), vagy erősen áldozathibáztató (aki miniszoknyában lép ki az utcára, esetleg aki bulizni jár, azt megerőszakolják). http://www.theguardian.com/world/2014/nov/24/hungary-policevictim-blaming-safety-video.

11 Az eseményekről 2019-ben részletes dokumentumfilm készült Untouchable címmel.

12 A „Me Too" kifejezést először Tarana Burke aktivista használta 2006-ban a Myspace közösségi oldalon.

13 A hazai \#MeToo kampány során megvádolt Marton László és Kerényi Miklós Gábor rövid idő után visszatérhettek a színházi életbe. 
hetőségét, mert nem ismerte fel a maszkot viselő elkövetőt. Az ügy ismertetésekor a médiában hosszan sorolták a gyanúsított titulusait és érdemeit, illetve egy televíziós interjúban - amely interjú adásba kerülése ellen számos szervezet és női parlamenti képviselő is tiltakozott, mivel sérti az erőszak áldozatának méltóságát - nagycsaládos hívő emberként ábrázolták, aki az igazságszolgáltatási rendszer áldozata. ${ }^{14}$

\section{Illusztráció a nök feletti kontrollra}

Az áldozathibáztatás, a „tehetsz róla” szlogen hazug és egyben rendkívül káros. Ez a „maga kereste a bajt” hozzáállás ráadásul végtelen korlátozásokhoz vezet. Vajon mi a biztonságos szoknyahossz: a térd vagy a boka? És mi van a vállakkal, a dekoltázszsal, a pillantásokkal? Csador, burka vagy éjszakai, esetleg teljes kijárási tilalom? Ez - ahogyan a fent említett példákból is kitűnik - már nem az áldozatról, hanem a döntéshozókról, illetve a hatalommal rendelkezők értékítéletéről, világnézetéről, meggyőződéseiről, hiedelmeiről és szokásairól, de legfőképpen a kontrollról szól.

A nők feletti kontroll korántsem egy középkori vagy a világ messzi zugaira korlátozódó ritkaság, hanem nagyon is velünk élő jelenség. Csak az elmúlt néhány évben az alábbi korlátozásokat vezették be nőkkel szemben. Magyarországon egy gyorsétteremből (Akirály 2015), Amerikában egy áruházból (Palombo 2014), egy neves fehérneműüzletből (Holohan 2014), egy fitneszstúdióból (Breezymama 2014), egy bírósági épületből (Willis 2019), Angliában egy hotelből (Rickman 2014) és egy uszodából (Johnston 2014), a világhálón egy időre a Facebookról (Rhodan 2014) zavartak ki szoptató anyákat, egy brit európai parlamenti képviselő (Farage 2016) szerint pedig legfeljebb a sarokban meghúzódva (LBC 2016) vállalható a gyerek etetése. Törökország miniszterelnöke szerint egy erényes nő nem nevet nyilvánosan, nem viselkedik kihívóan és nem csacsog feleslegesen a telefonon (Daily News 2014). Indiában felmerült a közbeszédben, hogy talán a női farmerviselet a zaklatás kiváltója (Saul-Yeshudas 2014). Thaiföld miniszterelnöke két brit turista meggyilkolását követően óva intette a nőnemű látogatókat a bikini viselésétől, „hacsak nem rondák” (Schneider 2014). Kazahsztánban a csipke fehérnemű az ellenség (BBC News 2014).

Az Instagram letiltotta Rupi Kaur indiai származású múvész fotóját, amelyen menstruációs vér látszódik (Sangani 2015). 2020 nyarán Írországban számos panasz hatására betiltottak egy tamponreklámot. A reklámban két nő társalog, mintha egy talkshow-ban lennének, és a megfelelő tamponhasználatról beszélnek edukációs jelleggel. A panaszok szerint a reklám tartalma lealacsonyító a nőkre nézve, illetve szexuális jellege van a reklámnak, amely káros a gyermekekre (Barr 2020).

A pornográfia elleni jogalkotás keretében Uganda miniszoknya-tilalmat vezetett be. (Abszurd következmény, hogy a kurta szoknyák viselésén feldühödött tömeg tagjai nyolc nőt vetkőztettek meztelenre, mondván: csak az új jogszabály végrehajtását segítik... [Alfred 2017]) A miniszoknyát és a rövidnadrágot Texasban (Ward

14 Az interjú készítésekor az ügyet harmadfokon tárgyalták. Az ügyröl elsőként a Népszabadság számolt be részletesen, ez után a cikk után kapott kiemelt médiafigyelmet az eljárás. 
2014) és Kanadában (CBC News 2014) is üldözik (Broderick 2014). 2018-ban egy floridai iskolában függesztettek fel egy diáklányt, aki térdnél szaggatott farmernadrágot viselt. Az iskola szerint a ruházat kiválasztásakor figyelemmel kell lenni a fiú tanulókra és azok hormonjaira (Pate 2018). Egy másik amerikai iskolában megtiltották, hogy a lányok sztreccsnadrágot viseljenek, mondván, a feszes ruhadarab vonzza a fiúk tekintetét, akik így másra sem tudnak figyelni (Cook 2014). Ugyanez megtörtént Angliában is, ahol a szabályt a lányok úgy értelmezték, hogy valószínűleg túl kövérek, és ezért feszül rajtuk a nadrág (Warren 2014). Kanadában a kivillanó melltartópánt (Klein 2014) és az ujjatlan póló is tiltólistás. Egy 17 éves lány leégett a napon, ezért felsője alatt nem viselt melltartót a középiskolában. Nemcsak megrótták, hanem sebtapaszt kellett ragasztania a mellbimbóira, illetve fel kellett vennie még egy pólót, hogy ne zavarja meg fiú iskolatársait (Yang 2018).

A lányoknak azonban arra is vigyázniuk kell, hogy ne essenek át a ló másik oldalára, mivel a nem elég szexis, a nemi szerepekkel ütköző, vagy a túl sokat takaró öltözéknek is van szankciója. Egy amerikai lányt az iskolai bálból küldtek haza, mivel nadrágot viselt (Stampler 2014). Szintén az USA-ban eltanácsoltak egy nyolcéves kisdiákot egy katolikus iskolából, arra hivatkozással, hogy lány létére fiúsan öltözik és viselkedik (Bergdahl 2014). ${ }^{15}$

A nőkkel szemben támasztott ellentmondásos, teljesíthetetlen és antagonisztikus elvárásokat szemléletesen foglalja össze a nagy port kavart Writings of a Furious Woman (2017) blogbejegyzés és az abból készült 2020-as Be a Lady They Said című videó. ${ }^{16}$ Egyes mondatok és jelenetek kifejezetten a nők elleni nemi erőszak, szexuális zaklatás esetén felmerülő áldozathibáztató kifejezéseket helyezik a középpontba. Mind a videó, mind az írás hamar visszhangra talált, és nagy népszerűségre tett szert. ${ }^{17}$

\section{A kisebbségekkel szembeni áldozathibáztatás}

\section{A feminista irodalmon túli elméletek}

Az áldozathibáztatás fogalma, ahogyan azt a tanulmány elején is említettük, nem a feminista mozgalmak, irodalom és kizárólag a feminista kriminológia koncepciója. Az áldozathibáztatás eredetileg más kontextusban jelent meg a társadalomtudományok területén.

A fogalmat és a jelenséget William Ryan (1971) pszichológus, szociológus használta és tette népszerúvé a Blaming the Victim című könyvében a kisebbségi és/vagy marginalizált helyzetben lévő csoportokra és ezeknek a csoportoknak a

15 A vallásszabadság nevében történő jogkorlátozásokra nem térünk ki, itt csak utalunk a strasbourgi esetjogra, amely szerint a burkaviselés tiltása összhangban áll az Európai Emberi Jogi Egyezménnyel, S.A.S v. France, ügyszám: 43835/11, 2014. július 1.

16 Be a Lady They Said videó:

https://vimeo.com/393253445?utm_campaign=2617611\&utm_source=affiliate\&utm_channel=affiliate\&cjevent=fefb203b59791 1ea800a00a10a240610.

17 A videó és annak üzenetével kapcsolatos kritikák azt emelték ki, hogy a videóból hiányoznak a - feminista irodalomban már megfogalmazott - megoldási javaslatok, hogy a lehetetlen elvárások útvesztőjéből hogyan lehet kitörni. Emellett többen hiányolták a videó férfi párját, bár a Gillette 2019-es reklámja, amely a "fiúk már csak ilyenek" hozzáállást teszi a középpontba, és rávilágít arra, hogy mennyire károsak ezek a férfiassághoz kapcsolódó hagyományos sztereotípiák (agresszió, hipermaszkulitás). https://www.youtube.com/watch?v=koPmuEyP3a0. 
szocioökonómiai helyzetére vonatkoztatva. Ryan múvében az 1965-ös Moynihanjelentés ${ }^{18}$ egyes állításaira reflektál, amely számos helyen racionalizálja az afroamerikai közösség hátrányos társadalmi, gazdasági helyzetét. A jelentés eredeti célja az afroamerikaiak szocioökonómiai helyzetének feltárása volt, de számos általánosító és sztereotip állítást fogalmazott meg. Ryan a Moynihan-jelentésben említett attitűdöt áldozathibáztatásnak tartotta, amelyet olyan ideológiaként definiált, amelyben a többségi társadalom tagjai igazolást találhatnak az afroamerikaikkal szembeni rasszizmusra és társadalmi igazságtalanságokra. Ryan könyve már felvázolja az igazságos világba vetett hit elméletének körvonalait. Ez pedig fenntartja a kialakult társadalmi status quót, védve a privilegizált csoport érdekeit. Ryan szerint gyakori jelenség az, amikor a többségi társadalom azt állítja a szegényebb, nehezebb helyzetben lévő emberekről, hogy azok maguk tehetnek a helyzetükről, lusták és érdektelenek abban, hogy javítsanak státuszukon, mivel jól megélnek az állam által biztosított támogatásokból, segélyekből. Ryan világosan rámutatott, hogy ezzel a hátrányos helyzetben lévő személyeket hibáztatják, és teljességgel figyelmen kívül hagyják a társadalmi struktúra befolyásoló szerepét. A bűnbakképzés korai elméletének egyik alappillére, hogy a nehezebb helyzetben lévő csoportokat úgy támadja, hogy ezzel politikai hasznot remél. Ez a jelenség erős hasonlóságot mutat a mai magyar közbeszéddel és politikai retorikával, ahogy a hajléktalanság kriminalizálásáról szóló lenti példa is mutatja.

Ha a szűkebb értelemben vett áldozathibáztatásra gondolunk, akkor az a büncselekmény megtörténte után jelenik meg. A korai elméletekben ugyanakkor az áldozathibáztatás egy olyan igazolási mechanizmus, amely ördögi körként sok esetben a média hatásával felerősítve olyan erőteljes következményekkel bír, hogy az akár bűncselekményekbe is torkollhat, különösen gyülölet-bűncselekményekbe, amikor csoport-hovatartozása miatt bántalmaznak valakit. A sérülékeny és stigmatizált csoportok tagjai a depriváció, a társadalmi igazságtalanság, az intézményi diszkrimináció, az előítéletek áldozatai. Ennek követeztében ezek a közösségek mint állítólagos gazdasági vagy egyéb veszélyforrások egy magasabb szintű hibáztatás célpontjaivá lesznek (Aberson 2015). Nir Rozmann és Sophie D. Walsh (2018) tanulmányukban rámutatnak arra, hogy minél magasabbnak értékelik a csoport általi veszélyt (legyen az gazdasági, politikai, kulturális, egészségügyi vagy más jellegű), annál magasabb lehet a csoporttal szembeni áldozathibáztatás a csoport saját kialakult helyzete miatt. A rasszizmus fals sztereotípiákat teremt, és egy bűncselekmény megtörténte után ezek a sztereotípiák igazolják a bűncselekmény megtörténtét. Ekkor újra megjelenik az áldo-

18 Daniel Patrick Moynihan szociológus által készített jelentés (ismertebb nevén Moynihan Report, teljes címe: The Negro Family: The Case For National Action) az afroamerikai közösség szocioökonómiai helyzetének gyökereit igyekezett feltárni. A jelentést több polgárjogi mozgalom és aktivista, illetve akadémiai szereplök is támadták, mert olyan megállapítások (problémakörök) is szerepeltek benne, mint hogy a családszerkezetük instabilabb, mint a fehér családoké, sok család matriarchális viszonyok között él, gettósodó körülmények között élnek, rosszabbul fizetett állásokban dolgoznak, a fiatalok által megtapasztalt kudarcok a bünözés felé tolják őket stb. A jelentéssel a legnagyobb probléma, hogy egyáltalán nem reflektál az állam, a társadalmi struktúra szerepére, hanem ahogy William Ryan is rávilágít - az afroamerikai közösséget teszi felelőssé ezekért a társadalmi problémákért.

A jelentés teljes egészében itt érhető el: https://web.stanford.edu/ mrosenfe/Moynihan's\%20The\%20Negro\%20Family.pdf. 
zathibáztatás, éppen azon elöítéletek alapján, amelyek miatt eredetileg megtámadták az áldozatot. Felmerül a kérdés, hogy mi az összekötő kapocs a strukturális rendszerből fakadó hátrányok áldozatai és a társadalmi gyűlöletből, felsőbbrendűségi érzésből elkövetett bűncselekmények sértetti csoportjai között. Az interakcionista, majd kritikai kriminológia egyre több figyelmet fordított arra, hogy megismerje a folyamatot, amelyben a társadalmi rendszer egyes szereplői - jelen esetben kiemelten az igazságszolgáltatás - megcímkéz egyes személyeket, ami a morális pánik továbbgyưrűző hatásának következtében egész társadalmi csoportok megbélyegzéséhez vezethet (Cohen 1973). A kritikai viktimológia azt vizsgálta, hogy bizonyos társadalmi folyamatok - például diszkrimináció, rasszizmus és társadalmi egyenlőtlenség, illetve a címke (a kritikai viktimológia átvette a címke fogalmát a címkézéselmélettől) - milyen hatással vannak az áldozattá válásra egyes társadalmi csoportok esetében (Newburn 2017: 371). A viktimológiai kutatások rámutattak arra, hogy a statisztikai adatok alapján a leggyakoribb áldozat fiatal, alacsony szocioökonómiai státusszal rendelkező, gyakran kisebbségi férfi (Virág 2016: 402, Newburn 2017: 371). ${ }^{19}$ A kritikai viktimológia a vulnerabilitás hat különböző területét határozta meg (Mawby-Walklate 1994: 45): lakóhely, társadalmi osztály, rassz, gender, kor, családi állapot. A felsorolt attribútumok növelhetik az áldozattá válás esélyeit, és részben ezeken a területeken jelenhet meg társadalmi egyenlőtlenség vagy diszkrimináció. A kritikai viktimológia, szorosan együtt a feminista kriminológiával, a figyelem középpontjába helyezte a családon belüli erőszak, illetve a szexuális erőszak női áldozatait és a hatalommal nem rendelkező áldozatokat, így a gyermekeket. Ezért mind a kritikai viktimológia, mind a feminista kriminológia fogalomtárát és elméleti keretét érdemes kiterjeszteni a strukturális rendszer egyenlőtlenségeinek áldozataira is, akik a hatalmi egyenlőtlenségekből adódóan nagyobb eséllyel válnak bűncselekmény áldozatává, és azon belül is szexuális erőszak, illetve társadalmi gyưlöletből elkövetett bűntettek áldozatává.

Az áldozathibáztatás más társadalmi csoportokkal szemben is jelen van, mind a közbeszédben, mind a politikai diskurzusban. A kisebbségekkel szembeni előítélet, diszkrimináció extrém formája az erőszakos gyülölet-bűncselekmény, amikor az elkövető azért bántalmazza a sértettet, mert az egy bizonyos - a tettes szemében ellenszenves - társadalmi csoport tagja. Mivel a gyülölet-bűncselekmények áldozatai jellemzően társadalmilag hátrányos helyzetű csoportok tagjai, a többségi társadalom áldozathibáztatása itt valószínűbb, mint alap-bűncselekmények esetén. A gyülöletbűncselekmények áldozatainak hibáztatása - csakúgy, mint maga a gyülölet-búncselekmény - különösen traumatizáló, mivel az áldozatot egy veleszületett vagy identitása alapját képező tulajdonsága miatt bántalmazzák és hibáztatják, továbbá a jelenség a társadalmi igazságtalanságok továbbélését is mutatja (Herek-Cogan-Gillis 2002).

19 A baloldali realizmus kriminológiai irányzatának egyik fontos felismerése volt az áldozati kutatások alapján, hogy a bűnözés mind földrajzi, mind szociális szempontból is a társadalom és a közösségek legsérülékenyebb csoportjaira koncentrálódik, vagyis a hátrányos helyzetben lévők nagyobb arányban válnak búncselekmény áldozatává. (Jones et al. 1986, idézi Borbíró 2016: 224). 
Ugyanakkor más - a gyülölet-bűncselekmények társadalmi megítélésével kapcsolatos - kutatások összetettebb képet mutatnak: esetenként a többség társadalmi egyenlőtlenségekkel szembeni fokozódó érzékenységét detektálták (MarcusNewhall et al. 2002). Rodin és mások (1989) kutatása azt igazolta, hogy az áldozat és az elkövető közötti hierarchikus viszony vagy a jelentős társadalmi státuszbeli különbségek - legalábbis bizonyos áldozati csoportok vonatkozásában - arra engedik következtetni a többséget, hogy diszkriminációalapú bűncselekmény történt.

Comstock (1991), Perry (2001), majd Lyons (2006: 46) is arra jutott kutatása során, hogy bizonyos, elsősorban az LMBT+ közösség tagjaival szemben elkövetett gyülölet-búncselekmények esetében a kívülállók hajlamosak az áldozatot hibáztatni és az elkövetőt részben vagy teljesen felmenteni. Az áldozathibáztatás mértéke attól függ, hogy valaki veleszületett vagy választható tulajdonságként fogja fel a nemi identitást vagy szexuális orientációt. Ha a védett tulajdonságot választhatónak tekinti, akkor a válaszadó szerint az áldozat logikusan befolyásolhatta volna a bűncselekmény megtörténtét, így az áldozathibáztatás foka magasabb lesz (Rodin et al. 1989). A melegek hibáztatása különösen szembetűnő a tárgyalóteremben, ahol gyakran elhangzik, hogy a heteroszexuális férfiakat természetükből eredően provokálja a homoszexualitás. Az angolszász területeken elterjedt a súlyosan diszkriminatív ún. „meleg pánik védekezés”, amikor az LMBT+ áldozattal szembeni emberölés vagy a testi sértés terheltje mint felelősséget kizáró vagy enyhítő körülményt hozza fel, hogy elvesztette az önkontrollját, amikor a homoszexuális vagy transzszexuális sértett közeledett felé. A büntetőjogi felelősség kizárásához vagy enyhítéséhez vezető védekezést a legtöbb államban ma már törvénnyel próbálják visszaszorítani. Az áldozathibáztató védekezés mint ügyvédi stratégia a magyar esetjogban is megjelent, ám a Kúria visszautasította (Bárd 2019).

\section{Illusztráció a másság elutasítására}

A 2020-as év globális társadalmi eseményei is rávilágítanak erre a körforgásra. Az Egyesült Államokból kiindult Black Lives Matter mozgalom újból felszínre hozta az afroamerikai közösségek marginalizált és diszkriminált helyzetét, amelynek két kiemelkedő mozgatórugója a feketék elleni rendőri erőszak és a koronavírus-helyzet volt. A korábban megfogalmazott elméleti koncepciót alapul véve a társadalmi egyenlőtlenségek és a hozzájuk kapcsolódó rasszizmus olyan elöítéletes képeket társít a feketékhez, mint hogy bünözők, de legalábbis gyanúsak és veszélyesek. Ezek a képzetek aztán súlyos, halállal végződő - sok esetben rasszista motivációjú - rendőri intézkedésekhez vezetnek. Az ilyen jellegú túlkapások gyakoriságát több kriminológiai kutatás is vizsgálta, és az adatok azt mutatják, hogy az Amerikai Egyesült Államokban a fekete férfiaknak 2,5-szer nagyobb az esélyük, hogy egy rendőr keze által haljanak meg, mint a fehér férfiaknak (Edwards et al. 2019). Egy kaliforniai kutatás pedig rávilágított arra, hogy a rendőrök aránytalanul többször állítanak meg és alkalmaznak erőszakot fekete személyekkel, mint más etnikai csoportokkal szemben (Peeples 2020). A kialakult előítéletekkel és sztereotípiákkal 
validálják ezeket a tetteket, hiszen a médiában gyakran megjelennek olyan cikkek, amelyek az áldozat bűnügyi elóéletére utalnak, vagy a rendőri intézkedés során tett vélt vagy valóságos magatartásukra (Dukes-Gaither 2017). ${ }^{20}$ Hasonló jelenség figyelhető meg a koronavírussal kapcsolatos járványügyi helyzet vonatkozásában is. Az Egyesült Államokban a lakosság arányaihoz képest az afroamerikaiak magasabb arányban fertőződtek meg vagy hunytak el a betegség következtében - és bizonyos államokban egy másik kisebbségre, a latinó közösségre is igaz ez a megállapítás (Levenson 2020). Ez több okra is visszavezethető: az egyik a fekete közösség rosszabb egészségügyi helyzete, a jobb egészségügyi szolgáltatásokhoz való hozzáférés hiánya, de az okokat abban is lehet keresni, hogy arányaiban több afroamerikai végez olyan munkát, amelyet nem lehet otthonról ellátni, valamint a zsúfoltabb városi lakhatásuk is befolyásolhatja a vírus fokozottabb terjedését. Ibrahim X. Kendi (2020) kutató publicisztikájában rámutat arra, hogy ebben a helyzetben is megjelenik a hibáztatás, és kiemeli, hogy mind a média, mind a politikusok a fekete közösséget hibáztatják a magas halálozási arányok, a szegénység és az elhízás, és általában a rossz döntéseik miatt, de az ezek mögött húzódó miértekre nem keresik a választ. Közép-Kelet-Európában is ehhez hasonló folyamatoknak lehettünk tanúi a roma kisebbség esetében (Uszkiewicz 2020). A sérülékeny és marginalizált helyzetben lévő roma közösségek a pandémia időszakában szintén találkoztak ezekkel a hibáztató mondatokkal. Berta Péter (2020) cikkében rámutatott, hogy a román hatóságok, média és elemzések miként kapcsolták össze a roma kisebbség tagjait és kultúrájukat a koronavírus terjedésével, felelőssé téve őket a járvány lokális megjelenéséért. Szegregátumban élő romák nehezen tudják tartani a társadalmi távolság alapvető szabályait, a higiéniás előírásokat és javaslatokat. Egyes romániai szegregátumokban a járvány gyors terjedéséért nem a szociális vagy gazdasági deprivációt látják megoldandó problémának, hanem a romák mentalitását, maradiságát és kultúráját tették felelőssé a viszonylag magas fertőzésszámért (Berta 2020). ${ }^{21}$ A járvány kitörésekor a valós probléma közép- és hosszú távú kezelése helyett rendészeti eszközökkel zártak le számos településrészt.

A hagyományosan védett közösségeken túl ${ }^{22}$ Magyarországon az áldozathibáztatás és a másság elutasításának további példája a szegénység, a hajléktalanság kriminalizálása. Ez minőségileg annyiban különbözik a fenti példáktól, hogy itt maga a vonatkozó jogszabály alapul előítéleten, azaz azon a premisszán, hogy a hajléktalanok maguk tehetnek helyzetükről, és egyszerú jogszabályi tiltással megszüntethető a jelenség. A kérdés többször megjárta az Alkotmánybíróságot: 2012-ben a testület még megsemmisítette a vonatkozó szabályozást mint ami az Alaptörvény emberi méltóságról szóló II. cikkébe ütközik, ${ }^{23}$ amire válaszként a parlamenti többség beleírta a kriminalizáció lehetőségét az Alaptörvénybe (TASZ 2018). ${ }^{24} \mathrm{Az}$ alkotmányos

20 George Floyd esetében hangsúlyozták, hogy hamis húszdollárossal próbált fizetni, Michael Brown állitólag dulakodott a rendőrökkel, és korábban vulgáris rapszöveget írt a drogokról és alkoholról, Eric Garner esetében pedig aláhúzták, hogy már korábban letartóztatták több kisebb súlyú búncselekmény miatt.

21 A publicisztikában példaként említett konkrét esetben egy romatemetésen a teljes közösség részt vett.

22 Lásd például a Btk. 216. §-ában szereplő felsorolást.

23 38/2012 (XI. 14.) AB határozat.

24 Magyarország Alaptörvénye, XXII. cikk. 
felhatalmazásnak megfelelően a parlament 2018. október 15-ei hatállyal módosította a szabálysértési törvényt. ${ }^{25} \mathrm{Az}$ új rendelkezés ismét megjárta az Alkotmánybíróságot, ezúttal azonban a testület nem állapított meg Alaptörvény-ellenességet. ${ }^{26}$ Két korábbi alkotmánybíró (Kiss-Lévay 2020) és három civil szervezet (Magyar Helsinki Bizottság-TASZ-Utcajogász 2018) is amicus curiaet nyújtott be a hajléktalanság alkotmányellenességének kimondását szorgalmazva. Az öt különvélemény ellenére, az Alkotmánybíróság szerint a szabály nem ütközik az Alaptörvénybe. ${ }^{27} \mathrm{~A}$ szabályozás beleillik általában a szegénység kriminalizálásának tágabb problémájába. ${ }^{28}$

Magyarországon immár tilos a lomizás, ${ }^{29}$ a szegénységgel összefüggésbe hozható falopás pedig akkor is a Btk. szerinti vétség, ha szabálysértési értékre követik el. ${ }^{30}$ A kukázást is betiltották, amíg az Alkotmánybíróság ki nem mondta, hogy a szabályozás ellentétes az alkotmánnyal. ${ }^{31}$ A szociális temetés intézménye is illeszkedik a sorba, amely a rászorulótól személyes közremúködést kíván meg a hozzátartozó temetése során, így maga köteles például mosdatni és felöltöztetni az elhunytat, az ő felelőssége a koporsó gépjármű nélküli szállítása a temetőn belül, neki kell kiásnia a sírt, neki kell elhelyeznie a halottat a sírban, majd visszatemetnie a földet. ${ }^{32} \mathrm{~A}$ szociális temetkezés bevezetése folyamatosan tolódik, először 2014-re, majd a 2019-re tervezték a jogszabály hatálybalépését. Az újabb halasztásról rendelkező intézkedés alapján a szociális temetés 2021-től kerül be a temetői szolgáltatások közé. A szegények (és nem pedig a szegénység) elleni küzdelem állami eszközeinek sorába illik a társadalombiztosítási szabályok szigorítása is. A szigorítás célja az „egészségügy potyautasainak" kiszűrése: ha valaki három hónapig nem fizeti a társadalombiztosítást (nincs bejelentve vagy nem fizeti maga után), törlik a tajszámát (MTI 2019).

A tárgyalóterem sem mentes az áldozathibáztató érvektől. Klasszikus áldozathibáztatásba bocsátkozott a védő egy 2009-es gyülölet-bűncselekmény ügyben. A vádlott a IX. kerületi Boráros térről induló 23-as buszon obszcén rasszista kijelentésekkel illette a roma utasokat, és a busz oldalát háromszor-négyszer erôteljesen megütötte. A buszsofőr rászólt a vádlottra, hogy fejezze be a hangoskodást, mire a vádlott közölte vele, hogy biztosan zsidó, mert nagy az orra, és menjen vissza Izraelbe. Ekkor az autóbusz egy utasa szólalt meg: „Nem kéne a zsidókat macerálni, mert én is az vagyok!” A vádlott ekkor a sértetthez lépett és fenyegetődzve azt üvöltötte neki, hogy „Most megdöglesz vagy hazatakarodsz Izraelbe, te rohadt zsidó rasszista! Hogy mersz te nyilatkozni Magyarországon arról, hogy zsidó vagy, és miért lopod a pénzünket?!” Ezt köve-

25 2012. évi II. törvény a szabálysértésekről, a szabálysértési eljárásról és a szabálysértési nyilvántartási rendszerről, XXIII. fejezet, 178/B. §.

26 19/2019. (VI. 18.) AB határozat.

27 Uo.

28 Tágabb elméleti keretbe foglalva a hajléktalanság kriminalizációja a büntető populizmus egyértelmú példája. L. Gönczöl 2021.

29 2012. évi CLXXXV. törvény a hulladékról, 43. § (2) bekezdés: „A lomtalanítás során közterületre helyezett hulladék a Koordináló szerv tulajdonát képezi és egyben a közszolgáltató birtokába kerül."

30 2012. évi C. törvény, 370.§ (2) bekezdés bi) pont.

31 176/2011. (XII. 29.) AB határozat.

32 2013. évi CXXXVIII. törvény a temetőkről és a temetkezésről szóló 1999. évi XLIII. törvény módosításáról, amelynek hatálybalépése többször módosult, legutóbb 2021-re. 
tően öklével állon ütötte és homlokon fejelte a sértettet, továbbá a sértett mellkasa felé ütött, amit a sértett kivédett. Végül pedig a vádlott leköpte a sértettet. A bántalmazás közben a vádlott az üvöltötte, hogy „Te rohadt zsidó, miattad vagyunk ilyen szarban, te költöd a pénzünket, miért nem takarodsz haza Izraelbe!” A bíróság közösség tagja elleni, bántalmazással elkövetett erőszak bűntettében állapította meg a felelősséget. ${ }^{33}$ Nem fogadta el azt a védői hivatkozást - amire egyébként az egyik tanú is utalt -, hogy a sértett tehet a büncselekményről, mert ha ő nem avatkozik közbe, akkor a vádlott nem követte volna el a bűncselekményt. Ahogy az indokolás fogalmazott: „Igen jellemző, és a jelen ügyre szó szerint alkalmazható a »ne szólj szám, nem fáj fejem « mondással jellemezhető hozzáállás, azonban az elítélendő kijelentéseket hangoztató vádlottal szemben megfogalmazott kritika és a sértett származásának kijelentése nyilvánvalóan nem adhat okot a bántalmazásra. A büntető törvénykönyvi tényállás megfogalmazásából következik, hogy Magyarországon semmilyen etnikai, nemzeti, faji hovatartozás miatt senkit nem érhet bántódás következmények nélkül. Mindezen bizonyítékok alapján a bíróság kétséget kizáróan megállapította a vádlott büntetőjogi felelősségét." ${ }^{34}$

\section{Az áldozathibáztatás okai}

\section{Az elkövetök neutralizációs technikái}

A neutralizációs technikák arra szolgálnak, hogy az elkövető tette és meggyőződése, önképe közötti ellentmondást, feszültséget feloldják (Hazani 1991: 137).

David Matza és Gresham Sykes (1957) neutralizációs elmélete szerint a bűnelkövető pontosan tisztában van azzal, hogy megsért egyes erkölcsi normákat, illetve társadalmi elvárásokat. Azonban nem véglegesen hagyja el a társadalmi rendet, hanem oda vissza kíván térni, és csak időlegesen semlegesít bizonyos morális és jogi értékeket. Erre a bủnelkövető többféle stratégiát alkalmazhat. Jellemző ezek közül a felelősség hárítása („A férfiaknak ez a vérében van.”), a károkozás relativizálása („Ő is élvezte.”; „Nem nagy ügy.”), a sértetti státusz tagadása („Megérdemelte.”; „Ő kezdte.”), az elítélők elítélése („Csak irigyek.”) vagy felsőbb értékekre történő hivatkozás („A család becsülete forgott kockán.”). A neutralizációs technikák között - a témakör szempontjából - kiemelendő, hogy az elkövető miként tekint az áldozatára. Egyes esetekben az elkövető úgy véli, hogy az áldozat kevésbé értékes ember, nem illeti meg a tisztelet, vagy akár dehumanizálhatja is őt, ami egyenesen a sértetti, áldozati státusz tagadásához vezethet. A ruandai népirtásról készült kutatás (Bryant et al. 2017) ${ }^{35}$ két újabb neutralizációs technikát is azonosított. Az egyik szerint az elkövető magát „jófiúként” igyekszik feltüntetni, hangsúlyozva, hogy ő képtelen lenne ilyen súlyú bűnök elkövetésére. A másik technika szerint az elkövető saját magát definiálja áldozatként, azt

33 Pesti Központi Kerületi Bíróság 27.B.IX.25.692/2010/6. számú ítélete, 2-3. oldal.

34 Uo. 6. oldal.

35 Korábban is készültek tanulmányok, elemzések a népirtás és a neutralizációs technikák magyarázatáról, például: Alvarez 1997, Neubacher 2006. 
állítva, hogy saját személye, a családja vagy az azonos etnikai csoportból származó személyek fenyegetettsége miatt és félelem hatására követte el tettét.

\section{Tekintélyelvüség}

Az autoriter személyiségú ember könnyebben veszi át a másság elutasításának gondolatát, és hamarabb találja meg a bűnbakot. Ám ahogy Stanley Milgram (1974) áramütéses vagy Philip Zimbardo (1973) szimulált börtönkísérletei bizonyították, „megfelelő” környezetben az emberek túlnyomó többsége elmegy a végletekig a másik hibáztatásában és megbüntetésében. Zimbardo (idézi Kerezsi és Gosztonyi [2016: 355]) így fogalmazott: „El kellett borzadnunk, amint láttuk, hogy hogy egyes fiúk (örök) úgy kezelnek másokat, mintha hitvány állatok lennének, örömüket lelik a kegyetlenségben, miközben mások (foglyok) szolgálatkész, engedelmes, dehumanizált gépekké váltak, akiket csak a menekülés, a saját egyéni túlélésük, valamint az őrök elleni halmozódó gyúlöletük foglalkoztatott.” A Milgram- és Zimbardo-kutatás kapcsán fontos kitérni a kritikákra is, például Erich Fromm (1973) szociálpszichológus kételkedik abban, hogy a két kutatás tényleges bizonyítóerővel bírna. Fromm úgy látja, hogy a kutatások nem vették figyelembe a résztvevők személyiségét: szerinte két különböző dolog a kegyetlen szabályokat követni, és akarni is így viselkedni. ${ }^{36}$

Morális pánik könnyen gerjeszthető, nem kell ehhez az Adorno-féle F-skála szerinti tekintélyelvű személyiségű emberek garmadája. Ha erre egy megfelelő autoritás rájátszik, bárkire ráfogható, hogy szerencsétlenségét csak önmagának köszönheti, legyen az a hajléktalan, otthonszülő vagy egy népszerútlen kisebbségi álláspont megfogalmazója.

Canto és munkatársai (2020) azt vizsgálták, hogy a jobboldali tekintélyelvűség skálán való elhelyezkedés és a szociális dominancia orientáció mértéke hatással van-e a szexuális erôszak női áldozatainak hibáztatására. Az eredmények alapján aki magasabb pontot ért el a tekintélyelvűség skálán, hajlamosabb volt az áldozathibáztatásra. Azoknak volt a leginkább áldozathibáztató attitűdje, akik mind a skálán, mind szociális dominancia pontokban magas eredményt értek el. ${ }^{37}$

\section{Utólag mindenki okos}

Baruch Fischhoff (1975) eredményei szerint a végkifejlet ismerete indokolatlanul növeli a vélelmezett előreláthatóság esélyét. Lopakodó determinizmusnak nevezte a jelenséget, amikor a megtörtént dolgokra az eredmény fényében úgy tekintünk, mintha másképp nem is történhettek volna meg, mintha azokat mindig is elöre lehetett volna látni. Például ha tudjuk, hogy valaki autóbalesetet szenvedett, tönkrement a házassága vagy drogos lett, ezeket a tragédiákat utólag prognosztizálható-

36 A Zimbardo-féle börtönkísérlet kapcsán számos módszertani és etikai aggály merült fel, például, hogy kisszámú volt a kiválasztott minta, amely nem reprezentálta megfelelően az egyesült államokbeli börtönnépességet, a résztvevőket irányították, illetve, hogy Zimbardo érzelmileg bevonódott a kísérletbe. Zimbardo ezt az utolsó kritikát elismeri, a többit nem. 2001-ben hasonló börtönkísérletet végzett Haslam és Reicher (2006), amelyből a BBC tévéműsort is készített, eredményeik szerint nem a hatalmi pozíció hatásásra éltek vissza a helyzetükkel, hanem mert azonosultak a kutatók céljaival.

37 Lásd még Szabó et al. (2017) és Kende et al. (2020). 
nak tartjuk az addig különösebben fel sem tűnő vezetési stílus, veszekedések, illetve a baráti társaság fényében.

Ronnie Janoff-Bulman és Christine Timko (1985) az utólagos bölcsesség vagy viszszatekintő torzítás jelenségét és annak hatását az áldozathibáztatás vonatkozásában vizsgálta. A kísérleti és a kontrollcsoportnak azonos szöveget olvastak fel, ám az utolsó mondat eltért: az egyik esetben az volt, hogy „Majd arra eszméltem, hogy megerőszakol.”, míg a másik befejezés szerint „Majd arra eszméltem, hogy hazavisz.” A kísérlet alanyait arra kérték, hogy próbáljanak meg a történet végétől elvonatkoztatni, és megtippelni, milyen eséllyel végződik úgy a történet, hogy (i) a nő elcsábítja a férfit; (ii) a férfi megerôszakolja a nőt; (iii) a férfi megveri a nőt, vagy (iv) a férfi egyszerűen hazaviszi a nőt. Azok, akik a bűncselekménybe torkolló végkifejletet ismerték, hajlamosabbak voltak előre látni azt, mint azok, akik a semleges változatot hallgatták.

A nemi erőszakos végkifejletet ismerő csoport fokozottabban tulajdonított a nőnek olyan tulajdonságokat (naiv, képtelen vigyázni magára; olyan típus, aki könnyen beadja a derekát) és magatartásmintákat (nem kellett volna piknikeznie a férfival; nem kellett volna felmennie a férfi lakására), amellyel provokálhatott egy potenciális erőszaktevőt. A látszólag semleges vagy mindennapi történések egészen eltérő fénybe kerülnek, amennyiben a történet kimenetele ismert. Erre példa, amikor a ma embere értetlenségét fejezi ki a zsidókkal szemben, akik nem hagyták el „időben” a nácizmus sújtotta államokat, mintha a harmincas évek zsidó közösségek tagjainak előre kellett volna látniuk a soát. Sajnos azonban az áldozatok a végkifejlet ismerete nélkül kénytelenek döntést hozni.

Janoff-Bulman és Timko azt is vizsgálta, hogy az áldozathibáztatás mennyire csökkenthető például azzal, hogy a sértett felelősségének újragondolására kérik a kísérleti alanyokat, a másik végkimenet fényében. Az nem különösebben váratlan a fent ismertetett eredmények fényében, hogy azok, akik először a semleges, majd másodszor a nemi erőszakos végződést hallgatták, a második alkalommal nagyobb felelősséget tulajdonítottak a nőnek. Az azonban talán meglepő, hogy akik először a nemi erőszakos, majd másodszor a semleges végződésű sztorit hallgatták, nem voltak hajlandók alább adni az áldozathibáztatásból. Ez a megállapítás összhangban áll Richard Nisbett és Lee Ross (1980) korábbi eredményeivel, amelyek szerint az erős impulzusok, élénk információk aránytalanul nagyobb hatást gyakorolnak az emberre, mint az érzelmileg semlegesek.

\section{Az igazságos világba vetett hit}

Nehéz egy olyan világban létezni, amely alapvetően igazságtalan: ahol jó embereket (is) sújtanak természeti katasztrófák, ahol ők is betegség és bűncselekmény áldozataivá válnak. Megpróbálunk a gyermekmesék tanulságának megfelelően hinni abban, hogy a rossz elnyeri büntetését és a jó méltó jutalmát. Walster (1966) eredményei szerint a társadalmi kapcsolatok ellenálló rendjébe vetett hitünket sem kívánjuk feladni. 
Az igazságos világba vetett hit olyannyira fontos az emberek számára saját pszichikai integritásuk fenntartásában, hogy hajlamosak még a tényeket is úgy torzítani, hogy azok végül mégiscsak - saját értékrendjük szerint - igazságos konzekvenciákat eredményezzenek. Ezzel élhetővé tesszük a minket körülvevő világot, amely így tervezhetővé, kiszámíthatóvá, előre láthatóvá és egyben igazságossá válik, vagy legalábbis annak tűnik.

Az 1960-as években Mervin J. Lerner $(1966,1980)$ tanulmányozta először az igazságos világ felfogásába vetett hit torzító hatását, és arra jutott, hogy létezik néhány tipikus módszer arra, hogy a világ eseményei beleilleszthetővé váljanak az igazságos világba vetett hitrendszerünkbe. Az egyik valamilyen felsőbb hatalom létezését tételezi, amely gondoskodik a világ egyensúlyának és igazságosságának helyreállításáról. („Minden rossz valamilyen felsőbb jó érdekében történik.” „Isten útjai kiszámíthatatlanok.” „Akit nagyon szeret az Isten, arra sokat helyez.”) A másik módszer újraértelmezi az események kimenetét, azok okait. Amikor ártatlanok igazságtalan szenvedését látjuk, mi magunk is szenvedünk, és ezt sokszor úgy tesszük magunk számunkra elviselhetőbbé, hogy a szenvedés áldozatát, az ő viselkedését vagy személyiségjegyeit tesszük felelőssé a kínjaiért. („Előző életében elkövetett bűnökért vezekel.” „Nem kellett volna felmennie a férfi lakására.” „Ki mint vet, úgy arat.” „Gondolom, nem véletlenül hagyta el a felesége.” „Azért köhögsz, mert nem vettél fel sálat.") Lerner ezt azzal a kísérletsorozattal bizonyította, ahol a beépített embert elektrosokkal kínozták, és ezt a történteket befolyásolni nem képes kísérleti alanyoknak bemutatták. Míg kezdetben a kísérleti alanyokat felzaklatta a szenvedés látványa, fokozatosan elkezdtek ítélkezni az áldozatról. Minél nagyobb volt a szenvedés mértéke, annál negatívabb volt a hangvétel. Ez magyarázható azzal is, hogy a szenvedés szemlélői így próbálják meg leküzdeni a tehetetlenségükből adódó frusztrációt; azzal, hogy így szeretnék megindokolni maguk előtt is, hogy velük és szeretteikkel ilyen nem történhet; és végül az igazságos világba vetett hit hiedelmével, hiszen tisztességes emberekkel ilyen szörnyűség nem történhet. ${ }^{38}$ Lerner elmélete megfelelő alapot biztosított a későbbi társadalmi egyenlőtlenségeket fenntartó rendszerigazoló sztereotípiák jobb megértéséhez is (Z. Papp 2017: 84).

\section{Az áldozattal való együttérzés nehézsége}

Az áldozattal együtt érezni fájdalmas teher. Ahogy Ezzat A. Fattah (2010: 72) fogalmaz: olykor egy állat szenvedése iránt több empátiát mutat a társadalom, mint egy, az áldozati státuszra érdemtelennek tekintett személy iránt. Fattah szerint léteznek társadalmi csoportok (példaként említi a drogfüggőket, hajléktalanokat, fogvatartottakat, prostituáltakat), akik helyzetükből fakadóan és az irányukban megjelenő ne-

38 Lerner egyébként akkor jutott erre a következtetésre, amikor Stanley Milgram engedelmességtanulmányai folytatásaként arra kereste a választ, hogy a diktatúrák hogyan képesek fenntartani a többségi támogatottságot akkor is, amikor az önkényuralmi rendszer kormányzati lépései csak nyomorúságot és szenvedést okoznak. 
gatív attitűd miatt könnyen válnak áldozattá, de a társadalom mégsem érez irántuk sajnálatot vagy empátiát, és sok esetben az elkövető tettét is enyhébben ítélik meg.

Szexuális jellegű bủncselekmények esetén, minél kevésbé felel meg a bűntett az erőszak mítoszának, annál kevesebb együttérzést kap az áldozat, és ezzel párhuzamosan az áldozathibáztatás mértéke és az elkövető felelősségének relativizálása is nő (Szabó-Virág 2017: 217). A hatalmi helyzetben lévő elkövetővel pedig könnyebb együtt érezni. Ezért is hajlamos a társadalom többsége az elkövetők nyelvezetét, érveit, neutralizációs technikáit elfogadni. Ezek az eredmények azért is aggasztóak, mert ahogy a tanulmány első felében rámutattunk, a szexuális visszaélések jelentős részét ismerősök, családtagok sérelmére követik el, akik nem illenek bele az erőszak mítoszának képébe.

\section{Az ideális áldozat koncepciója}

1986-ban jelent meg Nils Christie (1986) norvég kriminológus írása Az ideális áldozat címmel. A tanulmány hamar a viktimológiai szakirodalom alapmúve lett. Christie felvázolja az ideális áldozat képét, és arra mutat rá, hogy ha valaki kiesik a megfelelő áldozat sztereotip kategóriájából, akkor az áldozathibáztatás célpontjává válhat. Christie ad néhány támpontot, hogy mely attribútumok jellemzik a sztereotip ideális áldozatot: (i) az áldozat gyenge és sérülékeny, általában idős, fiatal vagy beteg; (ii) az áldozatot valamilyen nemes cél, tiszteletreméltó cselekmény megvalósítása közben éri a bűncselekmény; (iii) olyan helyen történik a bűntett, ami miatt az áldozat nem hibáztatható; (iv) az elkövető félelmetes; végül pedig (v) az elkövető ismeretlen, nincs kapcsolata az áldozattal. Az áldozati státusz nem egy fix címke, hanem társadalmilag konstruált és folyamatosan alakítható (Daly 2014: 378). Christie példát is hoz az ideális áldozatra: egy idős asszony, aki napközben éppen hazafelé tart beteg testvérétől, amikor egy ijesztő külsejű férfi megtámadja és kirabolja őt, hogy a pénzt kábítószerre vagy alkoholra költse.

A tipológia alapján szexuális jellegű búncselekmények vagy a családon belüli erőszak áldozatai nem illenek bele az ideális áldozat képébe, ezért is válhatnak, válnak az áldozathibáztatás célpontjává (Miért ment el bulizni? Miért ment haza egyedül késő este? Miért nem hagyta el a bántalmazó párját? stb.). Ha fent tárgyalt gyúlölet-bűncselekmények példáját nézzük, akkor ideális áldozatnak tekinthetőek például a szellemi fogyatékkal élő áldozatok. Christie (1986: 28) szerint az ideális áldozatokkal szembeni bủncselekmények szigorúbb és erőteljesebb állami fellépéssel járhatnak, de közben a fogyatékkal élők sérelmére elkövetett előítéletes cselekmények szinte láthatatlanok maradnak a hatóságok előtt (Mason-Bish 2018). Érdekes, hogy az ideális áldozati címke milyen gyorsan meg tud változni. Gilmour (2013) azt mutatja be, hogy Natascha Kampusch áldozati megítélése hogyan változott meg a szökése utáni időszakban. Kampusch elrablása idején ideális áldozat volt, gyermekként éppen az iskola felé tartott, amikor egy felnőtt férfi a kisteherautójával mellé állt és elrabolta. Kampusch a szökése után adott interjúkban - a sajtó és a társa- 
dalom többségének megrökönyödésére - nem szidta elrablóját, nem mondott róla rosszat, nem támadta őt. „A legkevésbé azt nem bocsátották meg nekem, hogy a tettest nem úgy ítéltem meg, ahogy azt a nyilvánosság elvárta. Nem akarták tôlem hallani, hogy abszolút gonosz nem létezik, hogy a fekete és a fehér nem különithetö el tisztán egymástól." (Kampusch 2010: 257-258) Ekkor sokan megkérdőjelezték Kampusch áldozati szerepét, többen úgy vélekedtek, hogy a végén már önszántából maradt a férfival - voltak olyan hangok, hogy valószínúleg Stockholm-szindrómában szenved, noha ezt maga Kampusch többször elutasította -, illetve több cikk is arra kereste a választ, hogy miért nem szökött el korábban, noha volt rá alkalma, amikor autóval Bécs környékén jártak. Natascha Kampusch önéletrajzi könyvének epilógusában így ír: „Az áldozat iránti részvét csalóka. Az emberek csak akkor szeretik az áldozatot, ha vele szemben fölényben érzik magukat." (Kampusch 2010: 256)

\section{Az áldozatok önvádja}

Carin Perilloux, Joshua Duntley és David Buss (2014) kutatásukban azt vizsgálták, hogy az erőszakot elszenvedett nők hogyan értékelik a nemi erőszakhoz vezető történéseket azokhoz a nőkhöz képest, akiknek a barátnőjét erőszakolták meg. Hat faktort határoztak meg, amely befolyással lehetett a bủncselekményre: az elkövető, az áldozat, a helyzet, az áldozat családja, a barátok és egyéb. A legtöbb kategória vonatkozásában nem mutatkozott különbség az áldozatok és az áldozatok barátnői csoportjában. Az elkövető és az áldozat szerepét azonban eltérően ítélték meg. Azok a nők, akik maguk is áldozatok voltak, sokkal nagyobb jelentőséget tulajdonítottak az áldozat viselkedésének, mint azok, akiknek az ismerőse vált sértetté. Míg az előbbi csoport tagjai a cselekmény megtörténtét átlagban 70 százalékban tulajdonították az elkövetőnek és 19 százalékban a sértett közrehatásának, addig ez az arány a sértettek ismerősei körében 82 és 9 százalék volt. A kutatás további érdekes megállapítása, hogy míg az áldozati csoport 65 százalékban a szexet és 22 százalékban a hatalmat jelölte meg a bűncselekmény motivációjaként, addig a sértettek ismerősei csak 48 százalékban jelölték meg a szexet és 27 százalékban a hatalmat mint mögöttes indokot.

Az eltérések több faktorral is magyarázhatók: az áldozatok ismerősei talán a barátnőikkel való szolidaritásukat fejezték ki azáltal, hogy kisebb jelentőséget tulajdonítottak az áldozat közrehatásának, mint maguk az áldozatok. Másrészt az áldozatok azáltal, hogy magukat tették felelőssé, úgy érezhették, hogy kontrollálhatják az eseményeket, és reménykedhettek, hogy amennyiben a jövőben másként viselkednek, másként öltözködnek, megelőzhetik a sértetté válást. A bűntudat, a szégyen, a csökkentértékűség, a „vesztesség” érzése, a feldolgozatlan harag önmaga ellen fordítja az áldozatot, aki az önvád miatt tovább traumatizálódik. Az önhibáztatás igazolása helyett és azzal épp ellenkezőleg sokkal inkább csökkenteni kellene az áldozat bűntudatát. 


\section{Konklúzió}

Az áldozathibáztatás mind az áldozatra, mind a társadalom egészére nézve káros következményekkel jár. Az áldozat elveszíti az önbizalmát és a hatóságokba vetett bizalmát, aminek következtében egy esetleges újbóli bűncselekményt követően kisebb eséllyel fog segítséget kérni. Az áldozathibáztatás komoly pszichés tüneteket is generálhat, mint például depresszió, étkezési vagy önértékelési zavarok. Az áldozathibáztatás következtében csökken a társadalom áldozatok iránti empátiája, érzékenysége. A jelenség továbbá eltereli a figyelmet az igazságszolgáltatási rendszer deficitjeiről és magáról az elkövetőről, aki valójában felelős a bűncselekményért. Másként fogalmazva, illetve tágabban értelmezve a problémát: az áldozathibáztatás a sértettre tolja a felelősséget a kialakult társadalmi struktúráért, a rendszerszintú igazságtalanságért vagy a konkrét búncselekményért. Búnelkövetés esetén az elkövető a sértettre hárítja egyéni felelősségét, aki amúgy is sérülékeny, és rendszeresen találkozik előítélettel, diszkriminációval, a hátrányos helyzetéből adódó nehézségekkel. Az olyan dimenziók, mint a társadalmi helyzet, a nem, az etnikai hovatartozás, illetve ezek interszekcióinak vizsgálata feltétele a „megbízható viktimológiának" (Borbíró 2016: 223), amely az áldozattá válás megelőzésére és az áldozattá válást követő folyamatokra megfelelő megoldásokkal tud szolgálni, és egyéni segítséget képes nyújtani. Minimumkövetelmény, hogy a rendszerszintű társadalmi problémák áldozatait ne viktimizálja tovább az igazságszolgáltatási rendszer. Ennél azonban sokkal messzebbre is lehetne menni.

Sok állam szembemegy a többség akaratával, amikor eltörli a halálbüntetést, lazít a büntetések szigorán, dekriminalizál bizonyos, a többségi erkölcs által megvetendőnek tartott magatartásokat, és általában is ellát egy felvilágosító, aufklärista funkciót. Ezeknek a feladatoknak a megtervezésekor és megvalósításakor, ahogyan arra a 2003-as Társadalmi Bűnmegelőzési Stratégia is rávilágít, figyelemmel kell lenni arra, hogy a bűnözéssel kapcsolatos problémák és hatások különbözőképpen érintik az egyes társadalmi csoportokat. Ha a bűnözés kezelésével kapcsolatos szerepkörök és felelősségi viszonyok tiszták és jól lehatárolhatóak, akkor sikeres lehet az áldozatpolitika. Ennek részeként elengedhetetlen az áldozatok tájékoztatása, komplex - lelki, anyagi, fizikai - támogatása, az állami, a civil és az egyházi szervezetek együttműködése, empatikus attitűd az eljárás során, a média részéről pedig a hiteles tájékoztatás. Ezek együttesen tehetik sikeressé az áldozatpolitikát. Ha az áldozatot fókuszba helyezzük, és az áldozati politikát prioritásként kezeljük, valamint ha az igazságszolgáltatás áldozatbaráti módon múködik, akkor az olyan üzenetet hordoz magában, amely eszköz lehet a széles körű áldozathibáztató társadalmi narratívák megváltoztatásához. ${ }^{39}$ Ám ha a fenti elvárásokat nem is teljesíti az állam, akkor is minimumkövetelmény, hogy ne szolgáltasson muníciót az intoleranciának, ne játsszon rá a bűnbakkeresésre, az előítéletekre, az F-skála szerinti tekintélyelvű

39 115/2003. (X. 28.) OGY határozat a társadalmi búnmegelőzés nemzeti stratégiájáról. 
személyiségjegyekre, és föleg ne az áldozatot hibáztassa a bűncselekmény megtörténtéért, hanem a jog szigorával lépjen fel ellene.

\section{Victim-blaming against minority crime victims}

Abstract: Often times when members of vulnerable minorities become victims of crime, a victim blaming attitude can be traced on the side of the justice system, the media and the general public. Victim blaming can be regarded as a form of secondary victimisation, since society leaves crime victims for a second time behind, misinterpreting or downplaying their sufferings, whitewashing perpetrators and diminishing state disapproval of committing the crime in question.

We present the widespread phenomenon of victim blaming, and discuss its devastating effect on both the crime victims and society in general. In the first part of the paper we discuss the history of the concept, before connecting it to the oppression of women, crimes of sexual nature, and violent offences against minorities. In the second part we present theories that might explain the phenomenon and the force of victim blaming.

Keywords: victim blaming, victimisation, violence against women, hate crimes

\section{Irodalom}

Aberson, C. L. (2015): Positive intergroup contact, negative intergroup contact, and threat as predictors of cognitive and affective dimensions of prejudice. Group Processes \& Intergroup Relations, 18(6): 743-760.

https://doi.org/10.1177/1368430214556699

Adorno, T. et al. (1950): The Authoritarian personality. New York: Harper.

Akiraly (2015): Kidobtak a Nyugati téri Mekiből egy szoptató anyát. 444.hu. https://444.hu/2015/05/21/kidobtak-a-nyugati-teri-mekibol-egy-szoptato-anyat/.

Alfred, C. (2017): Uganda's Miniskirt Ban Prompts Protests After Vigilante Strippings, Huffinton Post. http://www.huffingtonpost.com/2014/02/27/ugandaminiskirt-ban_n_4867061.html.

Alvarez, A. (1997): Adjusting to Genocide: The Techniques of Neutralization and the Holocaust. Social Science History, 21(2): 139-78.

Bárd P. (2019): A Kúria döntése a „meleg pánik védekezésről”. Jogesetek Magyarázata, 10(4): 5-10.

Barr, S. (2020): Ruling to ban tampon advert condemned as 'ridiculous' and a 'disgrace'. Independent. https://www.independent.co.uk/life-style/women/tampon-adverttampax-banned-uk-offensive-asai-criticism-a9645131.html.

BBC News (2011): SlutWalk' marches sparked by Toronto officer's remarks. https://www.bbc.com/news/world-us-canada-13320785.

BBC News (2014): Kazakhstan: Lace underwear ban sparks protests. http://www.bbc.com/news/blogs-news-from-elsewhere-26227943.html.

Bergdahl, E. (2014): This Tomboy Was Kicked Out Of School For Defying 'GodOrdained' Gender Roles. Mic. http://mic.com/articles/86235/this-tomboy-waskicked-out-of-school-for-defying-god-ordained-gender-roles. 
Berta, P. (2020): Ethnicizing a Pandemic: COVID-19, Culture Blaming, and Romanian Roma. Society for Romanian Studies Newsletter, 42(1): 13-16.

Bienek, S. - Krahé, B. (2011): Blaming the Victim and Exonerating the Perpetrator in Cases of Rape and Robbery: Is There a Double Standard? Journal of Interpersonal Violence, 26(9): 1785-1797. https://doi.org/10.1177/0886260510372945

Borbíró, A (2016): Realista kriminológia. In Borbíró A. - Gönczöl K. - Kerezsi K. Lévay M. (szerk.): Kriminológia. Budapest: Wolters Kluwer, 210-232.

Breezymama(2014)LAFitness Bans Momfrom BreastfeedinginLockerRoom. Breezymama. https://breezymama.com/2014/04/27/mom-banned-from-breastfeeding-in-lafitness-locker-room-shares-her-story/.

Broderick, R. (2014): A 15-Year-Old Girl Was Forced To Wear A „Shame Suit” After Her School Decided Her Dress Was Too Short Buzzfeed. http://www.buzzfeed.com/ ryanhatesthis/a-15-year-old-girl-was-forced-to-wear-a-shame-suit-after-her\#. uyg9edZBGg.

Bryant, E. et al. (2017): Techniques of Neutralization and Identity Work Among Accused Genocide. Social Problems, 64(4): 584-602. https://doi.org/10.1093/socpro/spx026

Buchwald, E. - Fletcher, P. - Roth, M. (1993): Transforming a rape culture. Minneapolis, MN: Milkweed Editions.

Burt, M. (1980): Cultural myths and supports for rape. Journal of Personality and Social Psychology, 38(2): 217-230. https://doi.org/10.1037//0022-3514.38.2.217

Canto, M. J. - San Martín, J. - Perles, F. - Vallejo, M. (2020): Persons Who Fear Freedom and Equality Are the Ones Who Most Blame Women Who are Victims of Acquaintance Rape. Violence Against Women, 0(0): 1-17. https://doi.org/10.1177/1077801220909896

CBC News (2014): Truro mom fights school dress code after shorts deemed too short. http://www.cbc.ca/news/canada/nova-scotia/truro-mom-fights-school-dress-codeafter-shorts-deemed-too-short-1.2641525.

Christie, N. (1986): The Ideal Victim. In Fattah E.A. (ed): From Crime Policy to Victim Policy. London: Palgrave Macmillan, 17-30. https://doi.org/10.1007/978-1-349-08305-3

Cohen, S. (1973): Folk Devils and Moral Panicks. London: Paladin.

Comstock, G. D. (1991): Violence Against Lesbians and Gay Men. New York: Columbia University Press. https://doi.org/10.7312/coms94560

Cook, T. (2014): Leggings and yoga pants now banned at Michigan High School. The River. https://rivergrandrapids.com/leggings-and-yoga-pants-now-banned-at-michiganhigh-school/.

Daily News (2014): Women should not laugh in public, Turkish deputy PM says. Hürriyet Daily News. http://www.hurriyetdailynews.com/women-should-not-laugh-in-publicturkish-deputy-pm-says-.aspx?pageID=238\&nID=69732\&NewsCatID=338.

Daly K. (2014) Reconceptualizing sexual victimization and justice. In Vanfraechem, I. - Pemberton, A. - Ndahinda, F. M. (eds): Justice for Victims. New York, NY: Routledge, 378-395. https://doi.org/10.4324/9780203094532 
Dukes, K. N. - Gaither, S. E. (2017): Black Racial Stereotypes and Victim Blaming: Implications for Media Coverage and Criminal Proceedings in Cases of Police Violence against Racial and Ethnic Minorities. Journal of Social Issue, 73(4): 789-807. https://doi.org/10.1111/josi.12248

Edwards, F. - Lee, H. - Esposito, M. (2019): Risk of being killed by police use of force in the United States by age, race-ethnicity, and sex. PNAS, 116(34): 16793-16798. https://doi.org/10.1073/pnas.1821204116

European Trauma Network: http://www.european-trauma-network.eu/index.php?id=447. Fattah, E. A. (2010): The Evolution of Young, Promising Discipline: Sixty Years of Victimology, a Retrospective and Prospective Look. In Shoham, S. G. - Knepper, P. Kett, M. (eds): International Handbook of Victimology. Taylor \& Francis Group, 43-94. https://doi.org/10.1201/EBK1420085471

Fischhoff, B. (1975): Hindsight is not equal to foresight: The effect of outcome knowledge on judgment under uncertainty. Journal of Experimental Psychology: Human Perception and Performance, 1(3): 288-299.

https://doi.org/10.1037/0096-1523.1.3.288

Fromm, E. (1973): The Anatomy Of Human Destructiveness. New York: Holt, Rinehart and Winston.

Gilmour, F. (2013): The Girl in the Cellar: Media Representations of Natascha Kampusch. Current Issues in Criminal Justice, 25(2): 645-666. https://doi.org/10.1080/10345329.2013.12035988

Glick, P. (2002): Sacrificial Lambs Dressed in Wolves' Clothing. In Newman, L. - Erber, R. (eds): Understanding Genocide: The Social Psychology of the Holocaust. OUP, 113-142. https://doi.org/10.1093/acprof:oso/9780195133622.001.0001

Gönczöl K. (2021): Criminal Justice in an Age of Populism, Achives of Criminology. Megjelenés alatt.

Haney, C. - Banks, C. W. - Zimbardo, P. (1973): A study of prisoners and guards in a simulated prison. Naval Research Review, 30: 4-17. https://doi.org/10.1007/978-1-349-24483-6_7

Hayes, R. M. - Lorenz, K. - Bell, K. A. (2013): Victim Blaming Others: Rape Myth Acceptance and the Just World Belief. Feminist Criminology, 8(3): 202-220. https://doi.org/10.1177/1557085113484788

Hazani, M. (1991): The universal applicability of the theory of neutralization: German youth coming to terms with the Holocaust. Crime, Law and Social Change, 15: 135-149. https://doi.org/10.1007/BF00172380

von Hentig, H. (1948): The Criminal and His Victim. New Haven: Yale University Press. Herek, G. M. - Cogan, J. C. - Gillis, R. J. (2002): Victim Experiences in Hate Crime Based on Sexual Orientation. Journal of Social Issues, 58(2): 319-339. https://doi.org/10.1111/1540-4560.00263

Holohan, M. (2014): Victoria's Secret store bans mom from breastfeeding. Today. 
https://www.today.com/parents/victorias-secret-store-bans-mom-breastfeeding2D11968546.

Howard, J. A. - Pike, K. C. (1986): Ideological Investment in Cognitive Processing: The Influence of Social Statuses on Attribution. Social Psychology Quarterly, 49(2): 154-167. https://doi.org/10.2307/2786726

Imhoff, R. - Banse, R. (2009): Ongoing Victim Suffering Increases Prejudice: The Case of Secondary Anti-Semitism. Psychological Science, 20(12): 1443-1447. https://doi.org/10.1111/j.1467-9280.2009.02457.x

Jámbor A. (2019): A nem létező magyar \#metoo mozgalom sírjára. Mérce. https://merce.hu/2019/03/19/a-nem-letezo-magyar-metoo-mozgalom-sirjara/. Janoff-Bulman, R. - Timko, C. (1985): Cognitive biases in blaming the victim. Journal of Experimental Social Psychology, 21(2): 161-177. https://doi.org/10.1016/0022-1031(85)90013-7

Johnston, I. (2014): Pool's food and drink rule bans babies being breastfed. Independent. http://www.independent.co.uk/news/uk/home-news/pools-food-and-drinkrule-bans-babies-being-breastfed-9655387.html.

Jones, T. - Young, J. -MacLean, B. (1986): The Islington Crime Survey - Crime, Victimization and Policing in Inner-city London. Aldershot: Gower.

Kampusch, N. (2010): 3096 nap. Budapest: Scolar Kiadó.

Kende, A. et al. (2020): Needs-Based Support for \#MeToo: Power and Morality Needs Shape Women's and Men's Support of the Campaign. Frontiers in Psychology, 11:1-19. https://doi.org/10.3389/fpsyg.2020.00593

Kendi, I. X (2020): Stop Blaming Black People for Dying of the Coronavirus. The Atlantic. https://www.theatlantic.com/ideas/archive/2020/04/race-and-blame/609946/?fbclid =IwAR3TNKZYPPKVe71ZA6bjIfmMzhGmD7Lmf6L83n4eypmvNKZ3orUhL7_AI-Y.

Kerezsi K. - Gosztonyi M. (2016): Az empirikus kutatás módszertana. In Borbíró A. - Gönczöl K. - Kerezsi K. - Lévay M. (szerk.): Kriminológia. Budapest: Wolters Kluwer, 331-354.

Kiss L. - Lévay M. (2020): Még egyszer a hajléktalanok büntethetőségéről. Közjogi Szemle, 13(1): 8-21.

Király, T. (1988): A büntetőhatalom korlátai. Magyar jog, 9: 730-743.

Klein, R. (2014): School Reportedly Sends Girls Home Over Visible Bra Straps. Huffington Post. http://www.huffingtonpost.com/2014/05/30/menihek-highschool-dress-code_n_5419763.html.

Kwan, R. (2011): Don't dress like a slut: Toronto cop. Excalibur Publications. http://www.excal.on.ca/dont-dress-like-a-slut-toronto-cop/.

LBC (2016): Farage: Mums 'Could Breastfeed In The Corner'. LBC.

http://www.lbc.co.uk/breastfeeding-mums-could-sit-in-corner-says-farage-101487. Lerner, M. - Simmons, C.H. (1966): The observer's reaction to the "innocent victim": Compassion or rejection? Journal of Personality and Social Psychology, 4(2): 203-210. https://doi.org/10.1037/h0023562 
Lerner, M. (1980): The Belief in a Just World: A Fundamental Delusion. Boston: Springer. https://doi.org/10.1007/978-1-4899-0448-5

Levenson, E. (2020): Why black Americans are at higher risk for coronavirus. CNN. https://edition.cnn.com/2020/04/07/us/coronavirus-black-americans-race/index.html.

Lőrincz N. (szerk.) (2009): Utcai szociáliskoordinátor-és gondozóképzés. Képzési segédanyag. Budapest: NSZFI.

Lynne Peeples (2020): What the data say about police brutality and racial bias and which reforms might work. Nature News. https:/www.nature.com/articles/ d41586-020-01846-z.

Lyons, C. J. (2006): Stigma or Sympathy? Attributions of Fault to Hate Crime Victims and Offenders. Social Psychology Quarterly, (69)1: 39-59. https://doi.org/10.1177/019027250606900104

Marcotte, A. (2012): Defense Attorney Blames 11-Year-Old Rape Victim Because That's His Job. SLATE. http://www.slate.com/blogs/xx_factor/2012/11/29/cleveland_ texas_rape_case_defense_attorney_calls_pre_teen_victim_a_spider.html.

Marcus-Newhall, A. - Palucki Black, L. - Baumann, J. (2002): Perceptions of Hate Crime Perpetrators and Victims As Influenced by Race, Political Orientation, and Peer Group. American Behavioral Scientist, 46(1):108-135.

https://doi.org/10.1177/0002764202046001008

Mason-Bish, H. (2018): Creating ideal victims in hate crime policy. In Duggan, M. (ed): Revisiting the 'Ideal Victim', Developments in Critical Victimology. Bristol: Policy Press, 43-63. https://doi.org/10.1332/policypress/9781447338765.001.0001

Mawby, R. I. - Walklate, S. (1994): Critical Victimology: International Perspectives. London: Sage. https://doi.org/10.4135/9781446250587

Milgram, S. (1974): Obedience to Authority: An Experimental View. London: Tavistock Publications.

MTI (2019): Az egészségügy potyautasait is kiszűri az új járuléktörvény. Adózóna. https://adozona.hu/2020_as_adovaltozasok/Az_egeszsegugy_potyautasait_is_ kiszuri_az_u_GMUQ9F.

Neubacher, F. (2006): How Can It Happen that Horrendous State Crimes are Perpetrated? An Overview of Criminological Theories. Journal of International Criminal Justice, 4: 787-99.

Newburn, T. (2017): Criminology. Abingdon, New York: Routledge. https://doi.org/10.4324/9781315629513

Nisbett, R. - Ross, L. (1980): Human Inference: Strategies and Shortcomings of Social Judgment. Pretince Hall Press.

Palombo, R. (2014): Woman banned from breastfeeding baby at Aventura Mall. Local 10. http://www.local10.com/news/woman-banned-from-breastfeeding-baby-at-aventuramall/27366694.

Pate, K. (2018): A Florida student was suspended for wearing ripped jeans. Insider. https://www.insider.com/student-suspended-for-ripped-knee-jeans-2018-9. 
Perilloux, C. - Duntley J. D. - Buss D. M. (2014): Blame attribution in sexual victimization. Personal and Individiual Differences, 63: 81-86. https://doi.org/10.1016/j.paid.2014.01.058

Perry, B. (2001): In the Name of Hate: Understanding Hate Crimes. New York: Routledge. https://doi.org/10.4324/9780203905135

Phone Farage (2016): LBC. http://www.lbc.co.uk/watch-nigel-farage-live-on-lbc-96464.

Pilkington, E. (2020): Harvey Weinstein tried to silence and blame victims. At trial it no longer worked. The Guardian. https://www.theguardian.com/world/2020/ feb/24/harvey-weinstein-trial-verdict-victims.

Police.hu (2014): Nők az erőszak árnyékában. Police.hu. http://www.police.hu/hirekes-informaciok/bunmegelozes/aktualis/nok-az-eroszak-arnyekaban.

Rab L. (2016): A rongybabává varázsolt nő - volt budai kórházigazgatót gyanúsítanak a szadista bosszúval. Népszabadság Online.

http://nol.hu/belfold/a-rongybabava-varazsolt-no-1609209.

Rees, S. et al. (2011): Lifetime prevalence of gender-based violence in women and the relationship with mental disorders and psychosocial function. JAMA, Vol. 306(5): 513-521. https://doi.org/10.1001/jama.2011.1098

Reicher, S. D. - Haslam, S. A. (2006): Rethinking the psychology of tyranny: The BBC Prison Study. British Journal of Social Psychology, 45: 1-40.

https://doi.org/10.1348/014466605X48998

Réz A. (2019): \#MeToo - Hogyan beszéljünk a szexuális visszaélésekről? Goethe Intézet. https://www.goethe.de/ins/hu/hu/kul/sup/klt/21485847.html.

Rhodan, M. (2014): Facebook Lifts Ban on Exposed Nipples in Breastfeeding Pictures. Time. http://time.com/2869849/facebook-breastfeeding-nipples/.

Rickman, D. (2014): In pictures: women breastfeeding ostentatiously at Claridge's protest. Independent. http://i100.independent.co.uk/article/in-pictures-womenbreastfeeding-ostentatiously-at-claridges-protest--xyGi2R-Rdg.

Rodin, M. - Price, J. - Sanchez, F. - McElligot, S. (1989): Derogation, Exclusion and Unfair Treatment of Persons with Social Flaws: Controllability of Social Flaw and the Attribution of Prejudice. Personality and Social Psychology Bulletin, 15(3): 439-451. https://doi.org/10.1177/0146167289153013

Rozmann, N. - Walsh, S. D. (2018): Perceived threat, blaming attribution, victim ethnicity and punishment. International Journal of Intercultural Relations, 66: 34-40. https://doi.org/10.1016/j.ijintrel.2018.06.004

Ryan, K. M. (2019): Rape Mythology and Victim Blaming as a Social Construct. In O’Donohue, W. T. - Schewe, P. A. (eds): Handbook of Sexual Assault and Sexual Assault Prevention. New York: Springer International Publishing.

https://doi.org/10.1007/978-3-030-23645-8

Ryan, W. (1971): Blaming the Victim. New York: Vintage Books. 
Sangani, R. (2015): Instagram deletes woman's period photos but her response is amazing. Telegraph. https://www.telegraph.co.uk/women/life/instagramdeletes-womans-period-photos-but-her-response-is-amazing/.

Saul, H. - Yesudas, K. J. (2014): 'Women should not wear jeans' remark sparks angry backlash in India. Independent. http://www.independent.co.uk/news/people/ kj-yesudas-women-should-not-wear-jeans-remark-sparks-angry-backlash-inindia-9772414.html.

Sex Educatio Alapítvány (2012): Utcai szociális munka prostitúcióban elő magyar nökkel Magyarországon és Zürichben. Iris.

Schneider, K. (2014): 'Only ugly people are safe in bikinis here'. Thailand's Prime Minister Prayuth Chan-ocha says. news.com.au. http://www.news.com.au/ travel/travel-updates/only-ugly-people-are-safe-in-bikinis-here-thailandsprime-minister-prayuth-chanocha-says/story-e6frfq80-1227062871750.

Schönbach, P. (1961): Reaktionen auf die antisemitische Welle im Winter 1959/60. Frankfurt am Main: Europäische Verlagsanstalt.

Stampler, L. (2014): Girl Gets Kicked Out of Prom for Having the Nerve to Wear Pants. Time. http://time.com/74193/girl-gets-kicked-out-of-prom-for-havingthe-nerve-to-wear-pants/.

Suarez, E. - Gadalla, T. M. (2010): Stop Blaming the Victim: A Meta-Analysis on Rape Myths. Journal of Interpersonal Violence, 25(11): 2010-2035.

https://doi.org/10.1177/0886260509354503

Sykes, G. M. - Matza, D. (1957): Techniques of Neutralization: Theory of Delinquency. American Sociological Review, 22(6): 664-670. https://doi.org/10.2307/2089195

Szabó J. - Virág Gy. (2017): A nemi erőszak mítosza. In Parti K. (szerk.): Szexuális erôszak: mítosz és valóság. Budapest: OKRI, 201-229.

Szabó M. et al. (2017) A felelősség paradoxona. A nemi erőszak mítoszok elfogadása és a társas identitás összefüggései. In Kovács M. (szerk.) Társadalmi nemek: elméleti megközelítések és kutatási eredmények. Budapest: Eötvös Kiadó, 117-140.

TASZ (2018): Hetedik elemzésünk az Alaptörvény legújabb módosításáról.

https://tasz.hu/cikkek/hetedik-elemzesunk-az-alaptorveny-legujabb-modositasarol. The Washington Post (2020): \#MeToo is at a crossroads in America. Around the world, it's just beginning. Washington Post. https://www.washingtonpost.com/ opinions/2020/05/08/metoo-around-the-world/?arc404=true.

Uszkiewicz E. (2020): Romák a járvány idején. MTA-ELTE Lendület SPECTRA Kutatócsoport honlapja. https://spectra.elte.hu/content/romak-a-jarvany-idejen.t.13578.

Vig D. (2016): Radikális kritikai irányzatok. In Borbíró A. - Gönczöl K. - Kerezsi K. Lévay M. (szerk.): Kriminológia. Budapest: Wolters Kluwer, 194-209.

Virág Gy. - Kó J. (1998): Lakossági vélemények a szexuális erőszakról. Kriminológiai és Kriminalisztikai Tanulmányok, 35: 250-276.

Virág Gy. (2001): A szexuális erőszak áldozatai. PhD-disszertáció, Miskolc: Miskolci Egyetem Állam- és Jogtudományi Kar. 
Virág Gy. (2016): Bünözés és média. Radikális kritikai irányzatok. In Borbíró A. - Gönczöl K. - Kerezsi K. - Lévay M. (szerk.): Kriminológia. Budapest: Wolters Kluwer, 395-419.

Virág Gy. - Kulcsár G. - Rosta A. (2016): Erőszakos bűnözés. In Borbíró A. - Gönczöl K. - Kerezsi K. - Lévay M. (szerk.): Kriminológia. Budapest: Wolters Kluwer, 553-602. Walster, E. (1966): Assignment of responsibility for an accident. J. Pers. Soc. Psychol, 3(1): 73-79. https://doi.org/10.1037/h0022733

Ward, A. (2014): University of Texas dress code banning 'revealing clothing' goes viral Austin Culturemap. http://austin.culturemap.com/news/city-life/06-04-14university-of-texas-nursing-schools-dress-code-jezebel-revealing-clothing/.

Warren, R. (2014): Schoolgirls Were Sent Home Because Their Trousers Were „Too Tight”. Buzzfeed. http://www.buzzfeed.com/rossalynwarren/schoolgirls-weresent-home-because-their-trousers-were-too-t\#.ejK0JeYMyp.

Willis, K. (2019): Mother says she was kicked out of court for breastfeeding baby. Boston 25 News. https://www.boston25news.com/news/trending-now/mothersays-she-was-kicked-out-of-court-for-breastfeeding-baby/946564899/.

Writings of a furious woman (2017): Be A Lady They Said. https:// writingsofafuriouswoman.wordpress.com/2017/12/09/be-a-lady-they-said/.

Yang, L. (2018): A 17-year-old says she was told to put Band-Aids on her breasts after school officials claimed her nipples were distracting male students. Insider. https://www.insider.com/braless-teenager-says-told-to-put-band-aids-onnipples-at-school-2018-4.

Z. Papp Zs. (2017): Az áldozathibáztatás pszichológiai magyarázatai. Alkalmazott pszichológia, 17(1): 77-97. https://doi.org/10.17627/ALKPSZICH.2017.1.77 